\title{
Krzysztof Wolański
}

PGNiG SA, Oddział Geologii i Eksploatacji

\section{Wojciech Zarudzki}

ORLEN Upstream Sp. z o.o.

\author{
Hubert Kiersnowski
}

Państwowy Instytut Geologiczny - Państwowy Instytut Badawczy

Marek Dohnalik, Katarzyna Drabik

Instytut Nafty i Gazu - Państwowy Instytut Badawczy

\section{Wykorzystanie tomografii komputerowej w badaniu rdzeni skał}

W artykule pokazano możliwości zastosowania rentgenowskiej tomografii komputerowej w badaniu metrowych odcinków rdzeni wiertniczych. Przedstawiono między innymi:

- wyniki analizy zależności pomiędzy wartościami absorpcji promieniowania rentgenowskiego a parametrami uzyskanymi z pomiarów laboratoryjnych (gęstość objętościowa, porowatość całkowita i efektywna) i otworowych (gęstość objętościowa, porowatość),

- analizę struktur sedymentacyjnych oraz wydzielanie stref zeszczelinowanych,

- porównanie opisu otrzymanego z tomografii komputerowej z zapisem sondy XRMITM.

Prezentowane wyniki uzyskano po przebadaniu około $100 \mathrm{~m}$ rdzenia reprezentującego utwory piaskowca czerwonego spągowca.

Słowa kluczowe: tomografia komputerowa (CT), piaskowiec czerwonego spągowca, porowatość, elektryczny mikroimager, obrazowanie rdzenia wiertniczego.

\section{Application of computed tomography (CT) in rock core analysis}

The aim of the paper is to show the applications of X-ray computed tomography in the study of the whole rock cores (one meter sections). The following applications are presented:

- results of dependency analysis between X-ray absorption values and parameters obtained from laboratory measurements (bulk density, total and effective porosity), and from the well log interpretation (bulk density, porosity),

- analysis of sedimentary structures,

- comparison of the description obtained from computed tomography with the XRMITM probe interpretation.

The presented results are based on measurements of about a 100 meters of core representing the Rotliegend Sandstone.

Key words: computed tomography, rotliegend sandstone, porosity, electrical micro imager, drill core imaging.

\section{Wstęp}

Tomografia rentgenowska (CT) umożliwia nieinwazyjne obrazowanie badanych przedmiotów. Jedno z pierwszych zastosowań rentgenowskiej tomografii komputerowej w geologii nastąpiło w 1974 roku $[7,10]$. Wynikiem pomiaru tomograficznego jest przestrzenny obraz przedstawiający zmiany absorpcji promieniowania rentgenowskiego [6, 13], które w znacznym stopniu odwzorowują zmienność gęstości skał. 
Istotną zaletą medycznych tomografów komputerowych jest możliwość przebadania dużych obiektów (w rozważanym przypadku: metrowych odcinków rdzenia) w bardzo krótkim czasie (poniżej $1 \mathrm{~min}$ ), wadą natomiast względnie niska rozdzielczość pomiaru. Trójwymiarowy obraz powstaje poprzez wyliczenie, podczas procesu rekonstrukcji, współczynników absorpcji (Hounsfield units, HU) dla każdego punktu badanego przedmiotu. Minimalny rozmiar rejestrowany przez urządzenie określony jest rozmiarem woksela. W przypadku urządzenia wykorzystanego do opisywanych badań rozmiar woksela wynosił $0,18 \times 0,18 \times 0,40 \mathrm{~mm}^{3}$. Najprostszym przykładem przedstawienia wyniku pomiaru CT jest obrazowanie struktury badanego odcinka rdzenia w postaci dwuwymiarowych przekrojów oraz trójwymiarowego obrazu (rysunek 1).

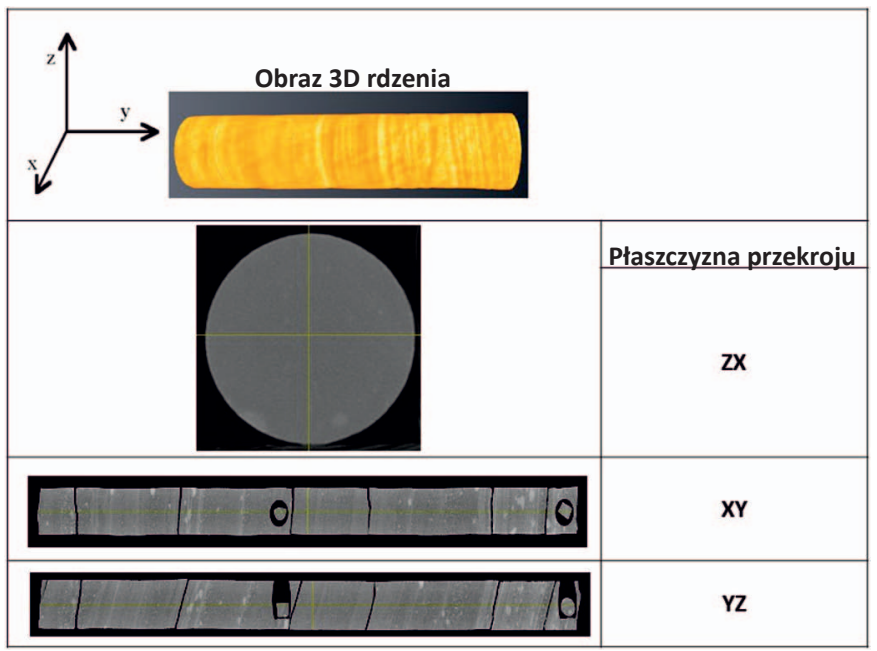

Rys. 1. Zestawienie najbardziej popularnych sposobów prezentacji obrazu tomograficznego odcinków rdzenia

W literaturze przedstawiono szereg innych możliwości zastosowania rentgenowskiej tomografii komputerowej w badaniu skał:

- wybór reprezentatywnego fragmentu rdzenia do dalszych badań, np. w przypadku kosztownych badań określających mechaniczne parametry skał wybór próbki na podstawie badań CT jest niemal niezbędny,

- ocena stopnia inwazji płuczki w rdzeń wiertniczy [1],

- ocena uszkodzenia rdzenia,

- ocena anizotropii struktury skał [12],

- analiza struktury porowej oraz jej obrazowanie przestrzenne [2],
- określenie kątów upadu warstw, określenie orientacji warstw i szczelin [8],

- obrazowanie podciągania kapilarnego skał [3],

- obserwacje zmiany struktury skały podczas badań mechanicznych lub po nich [11],

- wypieranie solanki poprzez zatłaczanie $\mathrm{CO}_{2}$ [9],

- uzupełnienie informacji otrzymanych z profilowania elektrycznym mikroimagerem.

Obrazowanie struktury rdzenia może być bardzo przydatne do uzupełnienia danych otrzymanych z zapisu elektrycznego mikroimagera. W celu porównania obrazu wewnętrznej ściany otworu z powierzchnią rdzenia wykorzystano autorski program dr. hab. Zbisława Tabora, który generuje obraz będący rozwinięciem powierzchni walca (rysunek 2). Na rysunku 3 przedstawiono przykład porównania obrazu wewnętrznej ściany otworu (obrazy kolorowe) z rozwiniętym obrazem rdzenia (obraz w odcieniach szarości). Zieloną strzałką zaznaczono szczelinę wypełnioną materiałem o podwyższonej gęstości, która nie została zarejestrowana na zapisie z sondy.

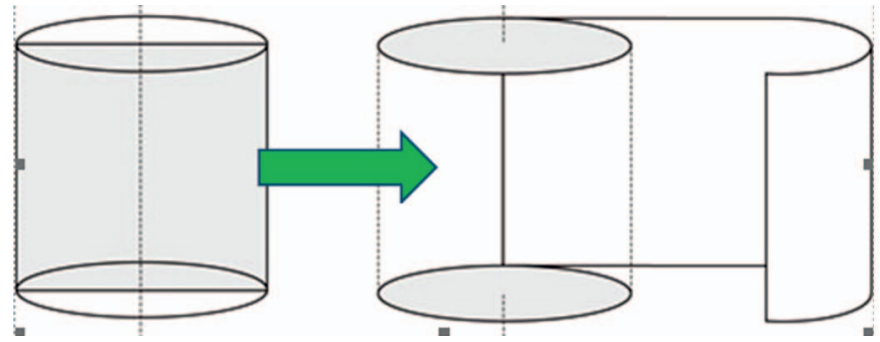

Rys. 2. Schemat otrzymywania rozwinięcia powierzchni walca

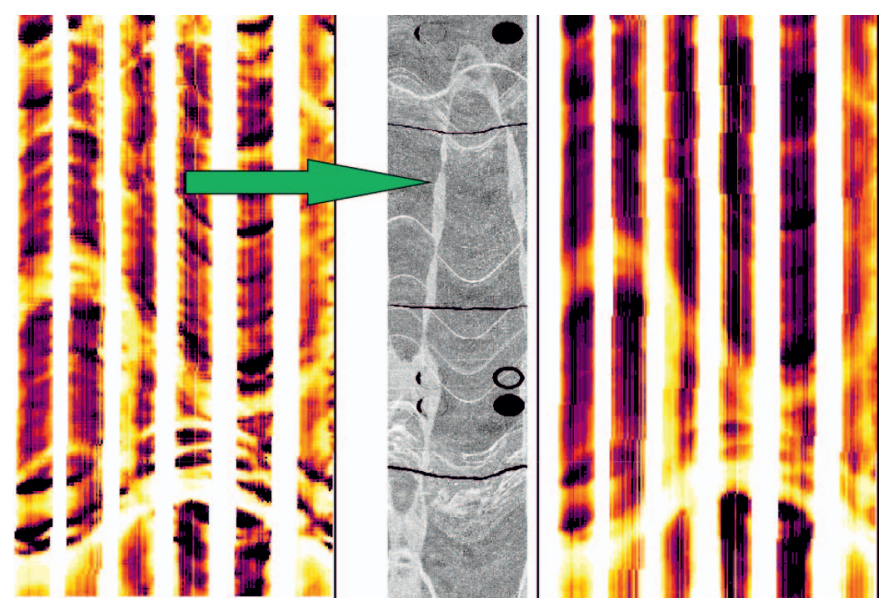

Rys. 3. Porównanie zapisu sondy XRMITM $\mathrm{z}$ tomograficznym obrazem rdzenia [4, 5]. Z lewej strony obraz z zapisu sondy, po filtracji (HORIZ7), z prawej obraz dynamiczny, w środku rozwinięcie powierzchni rdzenia z obrazu tomograficznego

\section{Metodyka}

W artykule zostały przedstawione wyniki porównania informacji uzyskanych z przetwarzania obrazów tomograficznych z wartościami gęstości objętościowej i porowato- ści otrzymanymi z pomiarów laboratoryjnych i interpretacji profilowań geofizyki otworowej oraz z makroskopowym opisem rdzenia. 
Prace te obejmowały przebadanie 102 skrzynek rdzenia, pobranego z otworu X, reprezentującego utwory piaskowca czerwonego spągowca. W celu porównania wartości gęstości objętościowej i porowatości z jednostkami absorpcji (HU) wygenerowano ciągłe profile zmian HU wzdłuż badanego rdzenia. Wykorzystano do tego autorski program napisany przez $\mathrm{dr}$. hab. Zbisława Tabora, który wyznacza średnie wartości HU dla danego przekroju rdzenia. Wynik działania tego algorytmu zamieszczono na rysunku 4. Z lewej strony widoczny jest obraz rozwinięcia walca, w środkowej kolumnie umieszczono profil wartości HU z pominięciem odcinków rdzenia, w których występowały spękania lub pobrano z nich próbki do badań. Powstałe w ten sposób przerwy uzupełniono poprzez interpolację danych i otrzymano wykres widoczny w trzeciej kolumnie.

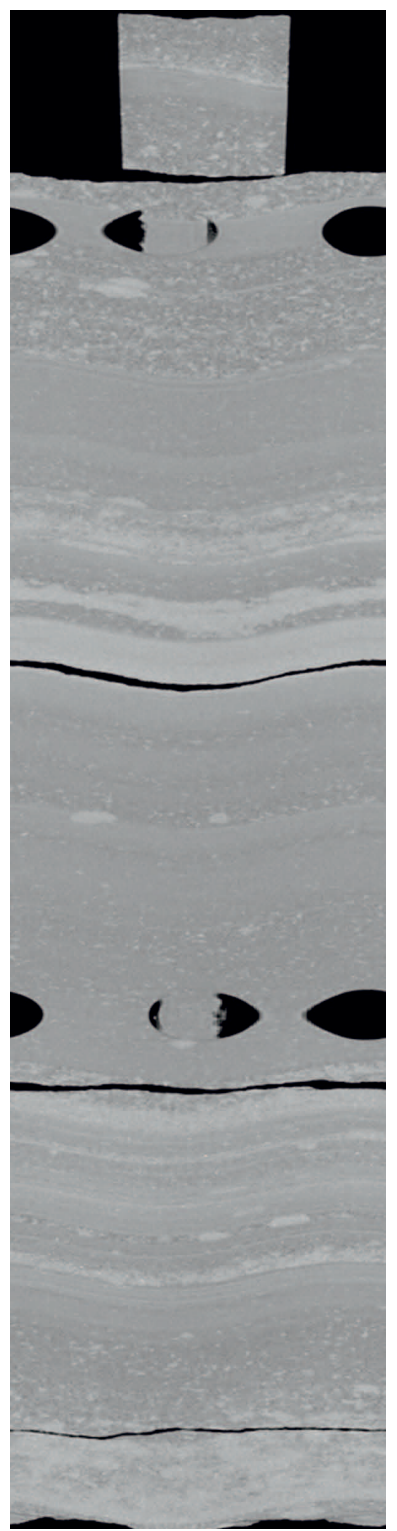

a) Rozwinięcie walca

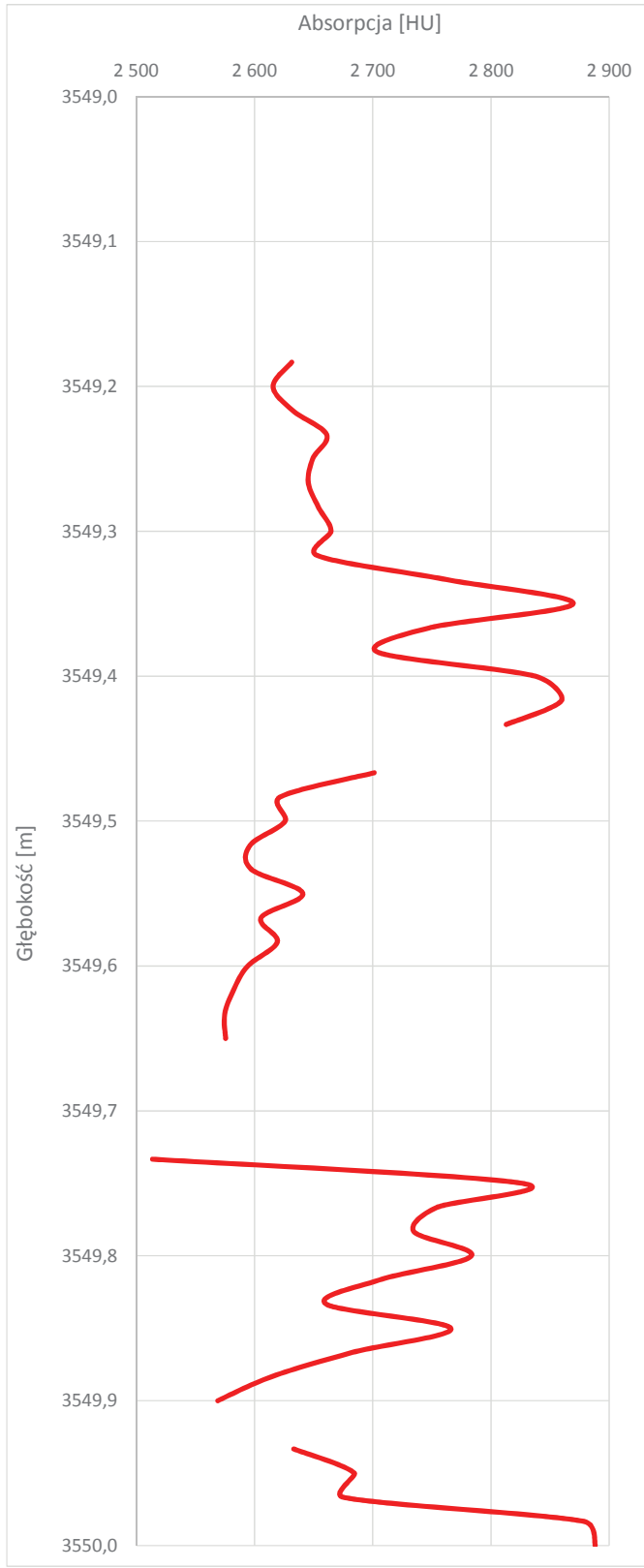

b) Profil absorpcji

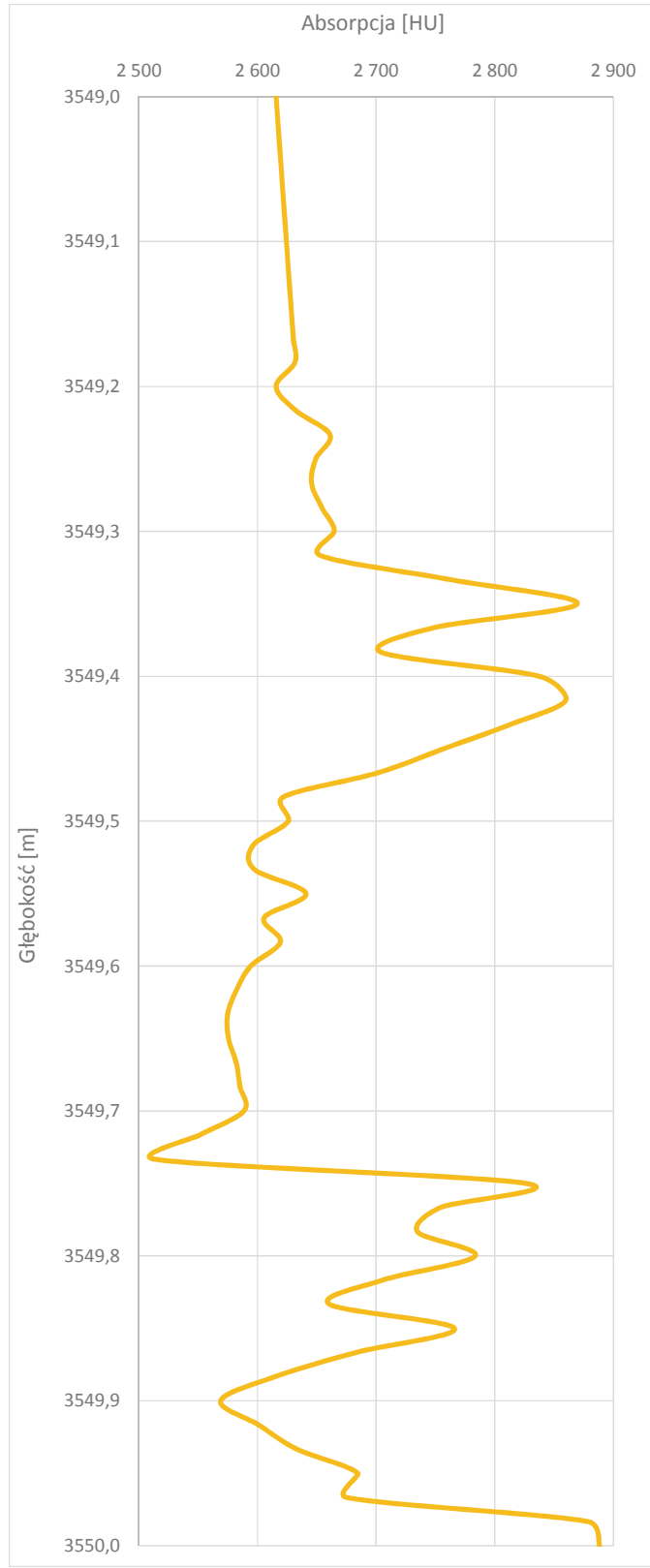

c) Uzupełniony profil absorpcji

Rys. 4. Przykład przetwarzania obrazu na profil absorpcji promieniowania rentgenowskiego [5]

\section{Wyniki}

\section{Korelacja wartości HU z wynikami badań laboratoryjnych}

W celu porównania wartości absorpcji z parametrami uzyskanymi laboratoryjnie dopasowano głębokość bada- nych próbek do profilu HU, a następnie zastosowano filtrację, aby wartości HU uśrednić z wielkości zbliżonej do wymiarów próbek rdzenia pobranych na badania laboratoryjne. 


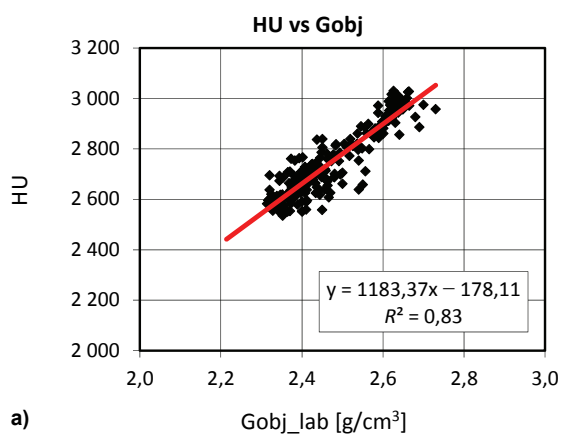

Rys. 5. Korelacja pomiędzy wartościami HU a gęstością objętościową (a) i współczynnikiem porowatości (b), $\mathrm{c}$ - dane z wykresu $5 \mathrm{~b}$ z podziałem na litofacje

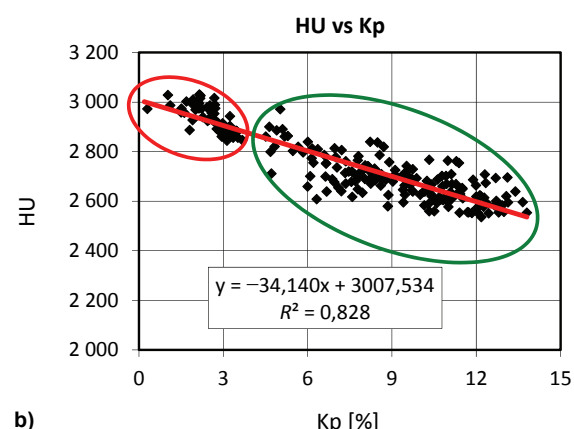

b)

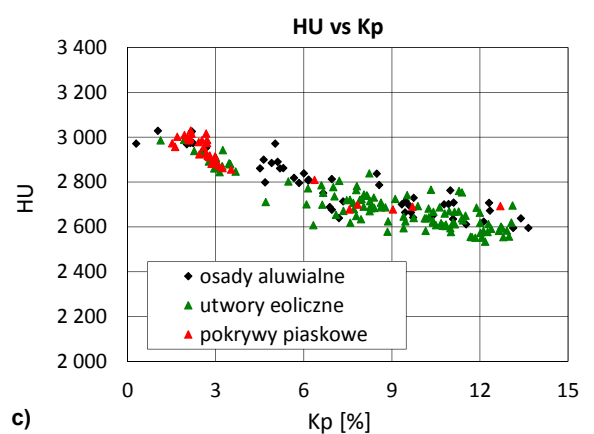

c) wartości współczynnika determinacji (dla RHOB: $R^{2}=0,78-$ rysunek 6a, dla PHI: $R^{2}=0,83$ - rysunek $\left.6 \mathrm{~b}\right)$.
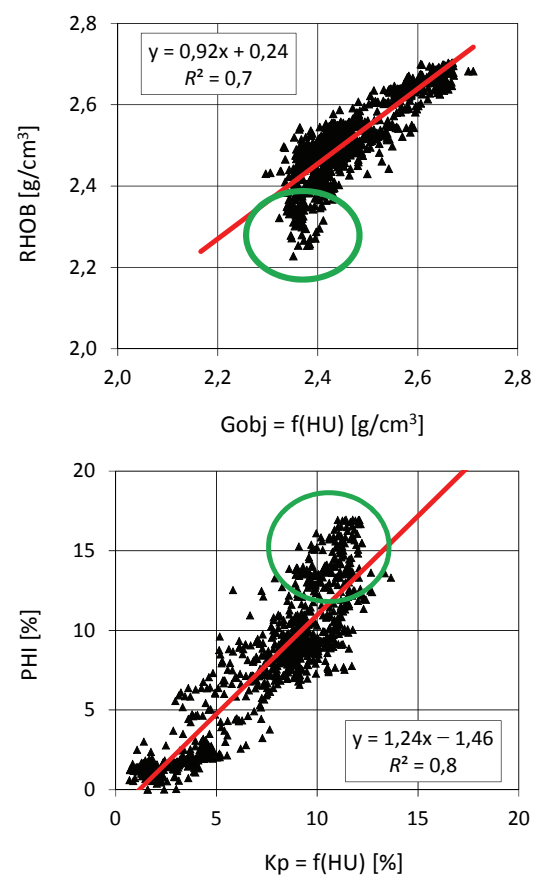

Rys. 6. Korelacje pomiędzy wartościami otrzymanymi z profilowania geofizyki otworowej a ciągłymi profilami wyników laboratoryjnych wyznaczonych na podstawie profilu HU

Mimo że większość danych wyznaczonych laboratoryjnie bardzo dobrze koreluje z danymi otworowymi (RHOB), na wykresie (rysunek 6a) widoczna jest grupa punktów, która wyraźnie odbiega od trendu liniowego. Otrzymana wcześniej zadowalająca korelacja pomiędzy wartościami HU a danymi laboratoryjnymi (gęstość objętościowa, porowatość) potwierdza prawidłowość utworzonych modeli matematycznych. Można sądzić, że brak trendu liniowego dla punktów oznaczonych na rysunku 6 zielonymi okręgami może wynikać z obniżenia jakości pomiarów geofizycznych. Należy zwrócić uwagę, że pogorszenie korelacji występuje dla danych zarejestrowanych $\mathrm{w}$ interwałach głębokości, w których widoczne jest znaczne powiększenie średnicy otworu. 


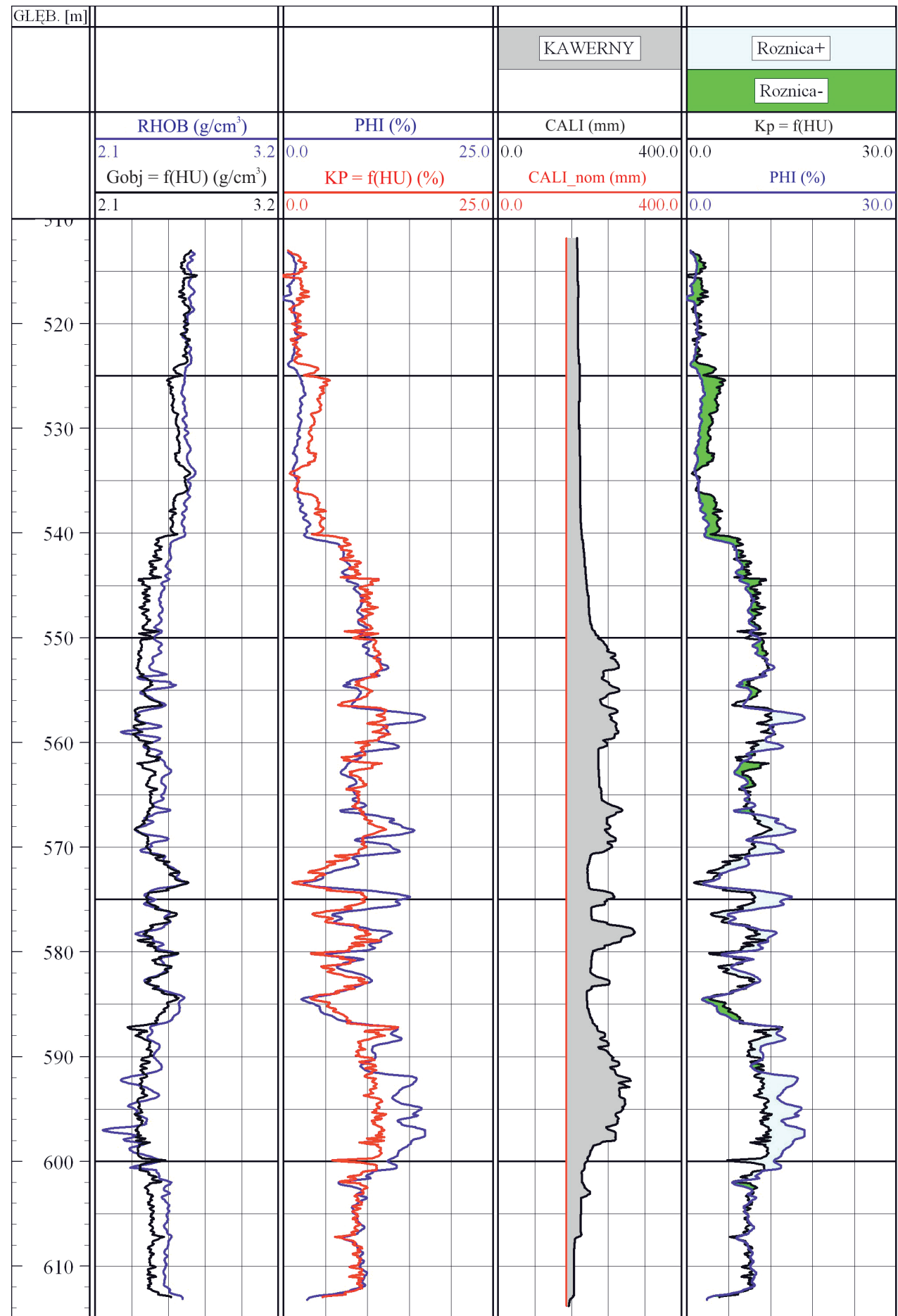

Rys. 7a), b) Porównanie profilowań otworowych (RHOB, PHI) z modelem matematycznym otrzymanym na podstawie badań laboratoryjnych i CT, c) profilowanie średnicy otworu, d) wykres pokazujący różnice pomiędzy porowatością wyznaczoną metodami otworowymi i laboratoryjnymi

\section{Przykład porównania badań tomografii komputerowej z zapisem sondy $\mathrm{XRMI}{ }^{\mathrm{TM}}$}

Wysoka rozdzielczość mikroopornościowego obrazu ściany otworu, uzyskanego z pomiaru sondą XRMITM firmy Halliburton, umożliwia zestawienie go z obrazami tomograficznymi rdzeni wiertniczych. Tego typu porównanie pozwala na niemal jednoznaczne dopasowanie głębokościowe rdzeni do pomiarów geofizycznych. Warunkiem prawidłowego dowiąza- nia głębokościowego jest obecność w profilu charakterystycznych elementów geologicznych, takich jak: niezgodności kątowe, szczeliny, warstwy o dużym kontraście oporności/gęstości (rysunek 8b). Wyniki tomografii komputerowej mogą również stanowić ważne uzupełnienie informacji otrzymywanych z pomiaru sondą XRMITM oraz pozwalają na zwiększenie do- 

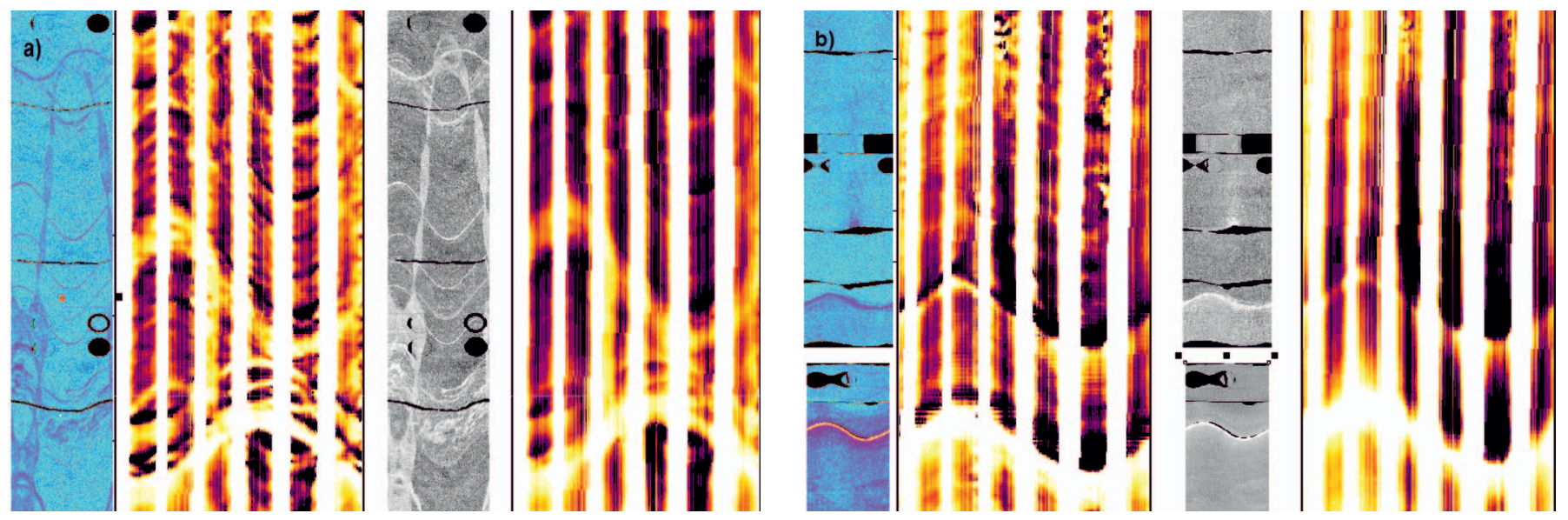

Rys. 8. Porównanie tomograficznego obrazu rdzenia z zapisem sondy XRMITM [4, 5]; a) wyraźnie zaznaczająca się na obrazie tomograficznym wysokokątowa szczelina wypełniona materiałem o podwyższonej gęstości, niewidoczna na obrazie mikroopornościowym ściany otworu; b) warstwy o małej miąższości oraz podwyższonej oporności i gęstości, pozwalające w sposób jednoznaczny na dowiązanie głębokościowe obrazu tomograficznego rdzenia do pomiaru XRMITM

kładności interpretacji obrazu mikroopornościowego. Obraz tomograficzny rdzenia w wielu przypadkach umożliwia prześledzenie w całości szczelin, które na obrazie mikroopornościowym ściany otworu zaznaczają się jedynie częściowo bądź też są zupełnie niewidoczne (rysunek 8a). Dzięki specyfice tomografii komputerowej (rozpoznawanie zmian gęstości badanego elementu) obraz tomograficzny rdzenia wiertniczego pozwala też jednoznacznie stwierdzić, czy szczelina zaznaczająca się na obrazie mikroopornościowym w postaci elementu o obniżonej oporności jest szczeliną otwartą, czy też wypełnioną materiałem o niskiej oporności. Tomograf rdzenia wiertniczego może stanowić także istotną pomoc podczas interpretacji obrazu XRMITM $\mathrm{W}$ interwałach, gdzie jakość pomiaru jest wy- raźnie obniżona (np. z powodu występowania struktur zniszczeniowych typu breakout). Wykonanie tomografii komputerowej rdzeni wiertniczych może być szczególnie istotne w przypadku, kiedy w otworze przeprowadzono tylko pomiar upadomierzem, rezygnując z sondy XRMITM. W przypadku podjęcia próby dowiązania obrazów tomograficznych rdzeni do wykresu strzałkowego, uzyskanego w wyniku przetwarzania danych z pomiaru upadomierzem, obecność charakterystycznych elementów geologicznych w profilu jest szczególnie istotna, ponieważ obraz RESMAP otrzymany z krzywych zarejestrowanych upadomierzem niesie zbyt mało informacji, aby na jego podstawie możliwe było jednoznaczne dowiązanie tomograficznego obrazu rdzenia do danych z upadomierza.

\section{Analiza struktur sedymentacyjnych oraz wydzielanie stref zeszczelinowanych}

Obrazy tomograficzne rdzeni mogą być wykorzystywane do opisu sedymentologicznego. Dla przebadanych 102-metrowych odcinków analiza porównawcza wykazała, że w większości przypadków makroskopowy opis rdzenia pokrywa się z opisem obrazu tomograficznego (rysunek 9a - cykliczne występowanie cienkich lamin piaskowca), a czasami pozwala zinterpretować szczegóły niewidoczne na rdzeniu (rysunek $9 b$ - mikrouskoki tektoniczne).
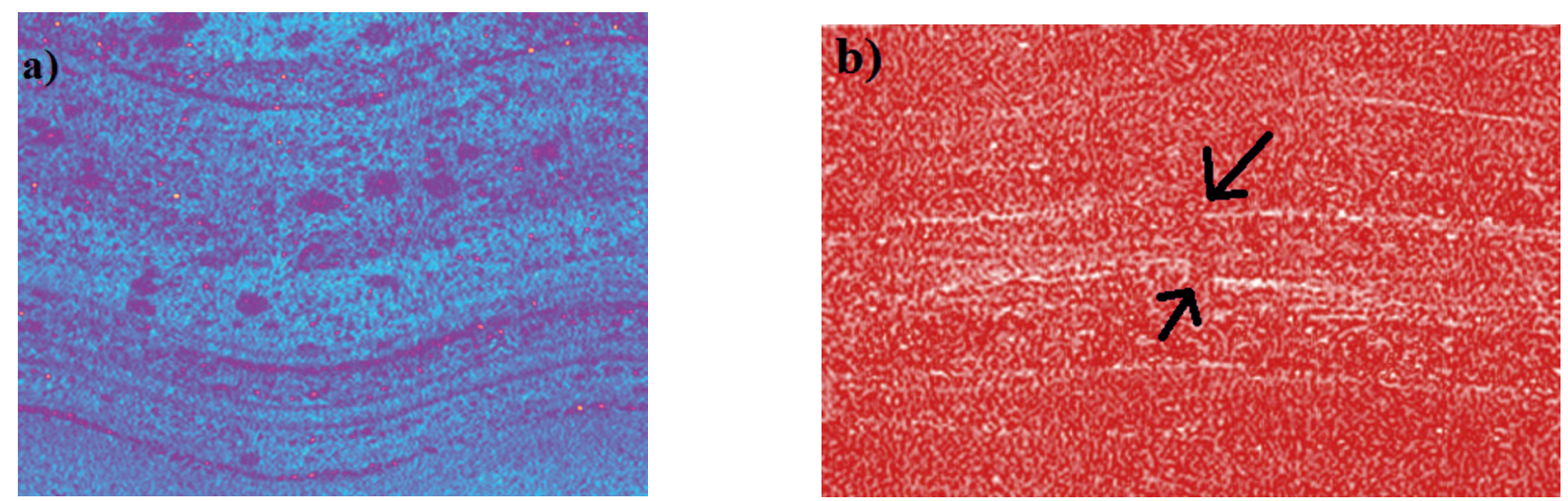

Rys. 9. Przykłady obrazów tomograficznych rdzenia w różnej palecie barw [5] 


\section{Podsumowanie i wnioski}

Celem artykułu było pokazanie możliwości zastosowania tomografii komputerowej w badaniu pełnych rdzeni wiertniczych. Przedstawione wyniki odnoszą się do pomiarów utworów piaskowca czerwonego spągowca. Szczególny nacisk położono na korelację pomiędzy wartościami HU a gęstością objętościową i porowatością wyznaczonymi laboratoryjnie oraz metodami geofizyki wiertniczej. Na podstawie przeprowadzonych badań wyciągnięto następujące wnioski:

1. Korelacja danych laboratoryjnych z profilowaniem absorpcji promieniowania X umożliwia wyliczenie ciągłych profili dla niektórych parametrów petrofizycznych.

2. Metoda CT może być szczególnie przydatna w przypadku badania otworów, dla których dostępny jest rdzeń, natomiast nie wykonano w nich badań geofizyki otworowej.

3. Metoda tomografii komputerowej może być stosowana jako nieniszczący sposób archiwizacji rdzeni wiertniczych jeszcze przed ich przecięciem i pobraniem prób do badań.

4. Profilowanie absorpcji HU może być wykorzystywane do dopasowania głębokości wiertniczej i geofizycznej.

5. Wyznaczone na podstawie badań laboratoryjnych modelowe wartości mogą być wykorzystane do korekty wartości gęstości objętościowej i porowatości uzyskanych metodami otworowymi.

6. Tomografia komputerowa pozwala na jednoznaczne rozróżnienie szczelin zamkniętych i otwartych, zaznaczających się na obrazie skanera mikroopornościowego w postaci elementów o obniżonej oporności, pozwala zatem na zwiększenie dokładności interpretacji pomiarów wykonanych sondą XRMITM.

7. Obraz tomograficzny rdzenia umożliwia obserwację elementów budowy geologicznej w tej części profilu, w której jakość obrazu uzyskanego z pomiaru skanerem mikroopornościowym jest obniżona.

8. Korelacja danych tomograficznych z zapisem sondy XRMITM pozwala na zorientowanie rdzenia względem kierunków świata.

9. Tomografia rdzeni w przypadku skał silikoklastycznych o różnej gradacji uziarnienia daje bardzo dobre rezultaty w zakresie szczegółowej analizy sedymentologicznej i litologicznej.

10. Należy mieć na uwadze, że wartości profilowania HU, które porównano z danymi laboratoryjnymi, zostały wyliczone (rysunek 4), a nie pomierzone, ponieważ próbki do badań laboratoryjnych pobrano przed badaniem tomograficznym rdzenia. Prawdopodobne jest, że w przypadku zachowania odwrotnej kolejności działań (wykonanie badań CT na świeżym, nieopróbowanym rdzeniu) otrzymano by jeszcze lepszą korelację. Ma to szczególnie istotne znaczenie w przypadku próbek, które zostały pobrane z niejednorodnych fragmentów rdzenia, gdyż dla tych fragmentów interpolowane wartości absorpcji mogą odbiegać od wartości rzeczywistych.

11. Prezentowane wyniki otrzymano $\mathrm{z}$ badań rdzenia reprezentującego utwory piaskowca czerwonego spągowca. Istotne jest także przeprowadzenie analogicznych badań na rdzeniach reprezentujących inne typy skał w celu sprawdzenia uniwersalności metody.

Prosimy cytować jako: Nafta-Gaz 2016, nr 12, s. 1035-1042, DOI: 10.18668/NG.2016.12.04

Artykuł nadesłano do Redakcji 7.11.2016 r. Zatwierdzono do druku 25.11.2016 r.

\section{Podziękowania}

Autorzy dziękują PGNiG SA oraz FX Energy Poland Sp. z o.o. (Grupa ORLEN) za sfinansowanie badań oraz możliwość przedstawienia wyników.

\section{Literatura}

[1] Chilingarian G.V., Mazzullo S.J., Rieke H.H.: Carbonate reservoir characterization: a geologic-engineering analysis, Part II. Elsevier 1996, vol. 44, s. 135-142.

[2] Christea P., Turberga P., Labiouseb V., Meulic R., Parriauxa A.: An X-ray computed tomography-based index to characterize the quality of cataclastic carbonate rock samples. Engineering Geology 2011, vol. 117, no. 3-4, s. 180-188.

[3] David C., Louis L., Menéndez B., Pons A., Fortin J., Stanchits S., Mengus J.M.: X-ray imaging of fluid flow in capillary imbibition experiments influence of compaction and localized deformation. [W:] Alshibli K.A., Reed A.H. (eds.):
Advances in Computed Tomography for Geomaterials: GeoX 2010. Wiley 2010, s. 262-269.

[4] Dohnalik M. i in.: Wykonanie tomografii na rdzeniach z odwiertu $x x x$. Dokumentacja INiG - PIB, nr arch. DK-5100917/14.

[5] Dohnalik M. i in.: Zastosowanie metody tomografii komputerowej do nieniszczacych badań catych rdzeni wiertniczych $w$ celu przeprowadzenia analizy struktur sedymentacyjnych $i$ wydzielania stref zeszczelinowanych. Dokumentacja INiG - PIB, nr arch. DK-4100-105/15.

[6] Dohnalik M., Zalewska J.: Niektóre zastosowania rent- 
genowskiej tomografii komputerowej w naukach o Ziemi. Nafta-Gaz 2008, nr 9, s. 547-556.

[7] Fourie S.: The cranial morphology of Thrinaxodon liorhinus Seeley. Annals of the South African Museum 1974, vol. 65, s. $337-400$.

[8] Louisa L., Wonga T.-F., Baudb P., Tembea S.: Imaging strain localization by X-ray computed tomography: discrete compaction bands in Diemelstadt sandstone. Journal of Structural Geology 2006, vol. 28, no. 5, s. 762-775.

[9] Okabe H., Tsuchiya Y., Pentland C.H., Iglauer S., Blunt M.J.: Residual $\mathrm{CO}_{2}$ Saturation Distributions in Rock Samples Measured by X-ray CT. [W:] Alshibli K.A., Reed A.H. (eds.): Advances in Computed Tomography for Geomaterials: GeoX 2010. Wiley 2010, s. 381-388.

[10] Stock S.R.: Microcomputed tomography: Methodology and applications. CRC Press 2009, s. 9, 10, 13, 25-26, 48.

[11] Watanabe Y., Lenoir N., Hall S.A., Otani J.: Strain field measurements in sand under triaxial compression using X-ray

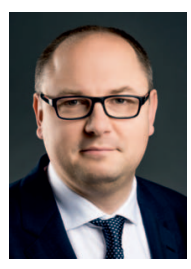

Mgr inż. Wojciech ZARUDZKI

Starszy specjalista petrofizyk

Biuro Analiz, Projektów i Dokumentacji Geologicznej

ORLEN Upstream Sp. z o.o.

ul. Prosta 70

00-838 Warszawa

E-mail: wojciech.zarudzki@orlen.pl

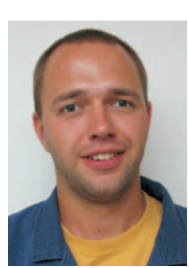

Dr inż. Marek DOHNALIK

Kierownik Zakładu Geofizyki Wiertniczej.

Instytut Nafty i Gazu - Państwowy Instytut Badawczy

ul. Lubicz 25 A

31-503 Kraków

E-mail: marek.dohnalik@inig.pl
CT data and digital image correlation. [W:] Alshibli K.A., Reed A.H. (eds.): Advances in Computed Tomography for Geomaterials: GeoX 2010. Wiley 2010, s. 76-83.

[12] Yuna T.S., Jeonga Y.J., Kimb K.Y., Minc K.-B.: Evaluation of rock anisotropy using $3 D X$-ray computed tomography. Engineering Geology 2013, vol. 163, s. 11-19.

[13] Zalewska J., Dohnalik M.: Rentgenowska mikrotomografia komputerowa $w$ badaniu skat. Nafta-Gaz 2008, nr 10, s. 683-690.

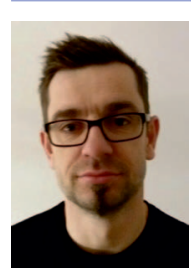

Krzysztof WOLAŃSKI

Starszy specjalista petrofizyk

PGNiG SA w Warszawie

Oddział Geologii i Eksploatacji

Dział Projektowy w Pile

ul. Boh. Westerplatte 15, 65-034 Zielona Góra

E-mail: krzysztof.wolanski@pgnig.pl

\section{Mgr Hubert KIERSNOWSKI}

Geolog, specjalizacja w zakresie sedymentologii i stratygrafii osadów klastycznych

Państwowy Instytut Geologiczny - Państwowy Instytut Badawczy

ul. Rakowiecka 4

00-975 Warszawa

E-mail:hkie@pgi.gov.pl

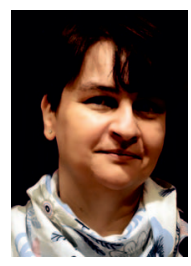

Mgr inż. Katarzyna DRABIK

Starszy specjalista inżynieryjno-techniczny

w Zakładzie Geofizyki Wiertniczej.

Instytut Nafty i Gazu - Państwowy Instytut Badawczy

ul. Lubicz 25 A

31-503 Kraków

E-mail:katarzyna.drabik@inig.pl 